\title{
生産緑地法改正に伴う農地転用の変化と住宅供給に関する研究
} 生産緑地法に関する研究（その 1$)$

\section{A STUDY ON THE CHANGES OF THE CONVERSIONS OF AGRICULTURAL LAND AND HOUSING SUPPLY AFTER THE AMENDMENT TO THE LAW OF PRODUCTIVE GREEN TRACT SYSTEM}

A study on the amendment to the law of productive green tract system (Part 1)

\author{
二武恭子*, 中山 徹** \\ Kyoko NIBU and Toru NAKAYAMA
}

\begin{abstract}
We investigated a tend of the conversion of agricultural land and housing supply.
The results are as follows:

1. Many of the agricultural land were conversed as soon as the amendment to the law of productive green tract system. Many of them conversed to parking lots. Those will be changed another buildings after that.

2. The supply of rental apartments has increased. But, those are below the targeted housing standard and many residents are not contented with the apartments.

3. The agricultural land in the city area will be converted more slowly. We need to build up a new system for the conversions.
\end{abstract}

Keywords: the law of productive green tract system, agricultural land in the city area, the conversion of agricultural land, agricultural land for building site, housing supply 生産緑地法, 市街化区域内農地, 農地転用, 宅地化農地, 住宅供給

\section{1. 研究の背景と目的}

1980年代後半（バブル経済期）における地価高騰を受け、市街化 区域内農地について、税制等の問題が取り上げられた。そして、平 成3年に生産緑地法が改正され、生産緑地地区は「緑地として保全 される農地」として、都市計画上に位置づけられた。生産緑地指定 を受けなかった市街化区域内農地（以下、宅地化農地と呼ぶ）に関 しては、計画的な宅地化を図る土地として、11都府県190の特定市 において宅地並み課税の対象となった。宅地化農地の転用増加によ る宅地の供給增加によって、地価安定を期待したものである。しか し、生産緑地指定が早急に行われ、その選択が農地所有者の意向に 委衫られていたことなどから、農地と宅地の混在化がより進むので はないかと䀣念されていた注1)。

生産緑地指定の状況やその特徵については、東京都立川市を事例

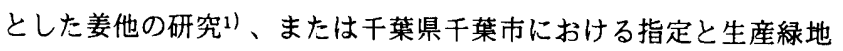
周辺の土地利用や所有者の意向との関連に関する斎藤他の研究 ${ }^{2)}$ か 挙げられる。また、千葉県流山市を事例とした市街化区域内農地の 宅地化実態に関する能見他の研究3)、横浜市を事例とした三㴊他の 研究4)が行われている。日本建築学会都市計画委員会では、「アー バンフリンジの土地利用」と題し、生産緑地法改正の概要、改正に おける都市農地の問題点等についての研究愍談会が行われた注1)。
そのなかて、市街化区域内農地の約 $69 \%$ にあたる宅地化農地につ いてどのような住宅供給があり市街地形成されたか、生産緑地地区 が都市環境のためにどう保全されるかという問題提起がなされた。 公共公益的要素を含んだ都市農地のあり方や住宅政策との連携につ いての議論が求められていることが挙げられている。また、建築学 会関東支部住宅問題専門研究委員会でも「都市農地と住宅まちづく り」と題したシンポジウムが行われており注2)、ここでは主に宅地 化動向に関して、農業側からと開発者側からの検討がされている。 そして、市街化区域内の宅地化農地と生産緑地、既存宅地の混在状 況が大きな問題であり、その改善方法の模索が課題とされている。

農地転用によって宅地の供給增加を図ること、それによって良好 な住宅を供給することが、生産緑地法改正の大きな目的のひとつで ある。既往研究の多くは、個々の特定市における農地転用、宅地化 動问について検討されているものの、全国的な状況の把握は十分で あるとはいえない。また農地転用の用途、特に住宅への転用に関し ては、供給住宅の内容に関する研究はなされていない。行政資料に おいても、農林水産省では農地転用面積の把握を行っているが、市 街化区域内・外や特定市市街化区域に限定した調査は行っていない。 また、建設省では一部調查がされているものの、転用の用途や、供 給住宅の内容等については調査されていない。
*広島県 廿日市 土木建築事務所

** 奈良女子大学生活環境学部人間環境学科 助教授・工博
Office of Civil Engineering and Architecture, City of Hatsukaichi, Hiroshima Prefecture

Assoc. Prof., Dept. of Human Environment, Faculty of Human Life and Environment, Nara Women's Univ., Dr. Eng. 
一方、法改正に伴う関連税制の改正があり、生産緑地には税制上 の優遇措置が取られているが、長期営農継続制度および相続税納税 猶予制度は廃止された。これにより宅地並み課税の導入が決定した が、導入当初の 4 年間については負担調整措置がとられ、課税額に 負担調整率を乗じた額を納税することとされた。また、平成 4 年か ら施行された地価税についても導入措置として平成 9 年からの課税 が決定している（表1）。また、早期の計画的宅地化には固定資産 税の優遇措置がとられ、住宅供給の誘導が図られた。これらのこと から、平成7年までの農地転用を検討することにより、法改正によ る農地の変化を把握できるのではないかと考える。改正の影響を受 けた急激な転用が一段落したと考えられるからである。

そこで本研究 (その1) では、(1)平成7年までの特定市における 農地転用について全国的な状況を把握する（本論 2，3 章）(2)農地 転用によりどのような住宅が供給されているかを明らかにする（本 論 4 章）(3)転用により供給された住宅（以下、転用住宅と呼ぶ）の 居住者の意識を明らかにする (本論 5 章) ことを通じ、農地転用に 関する今後の制度的課題を検討することを目的とする。注3)

\section{2. 全国の農地転用状況}

\section{2-1 農地転用の推移}

まず、法改正前から特定市の農地転用の推移について検討する。 農林水産省「農地の移動と転用」5)では全国の市町村別農地転用の 実態が集計されている。しかし生産緑地法との関係で変化を捉えて いないため、昭和 58 年から平成 6 年までの特定市の農地法 4 条 5 条届 出面積を取り上げ、新たに各都府県ことに集計した（図 1 ）。この グラフから、昭和 61 年頃に転用增加の傾向があったことがわかる。 これはバフル経済期の地価高騰により、土地開発が盛んに行われて いたためと思われる。生産緑地法改正直後の平成 4 年に、各都府県 で急激に転用が増加している。その後は徐々に減少し、平成6年に は、ほほ改正前の水染に戻っている。転用面積では神奈川県、埼玉

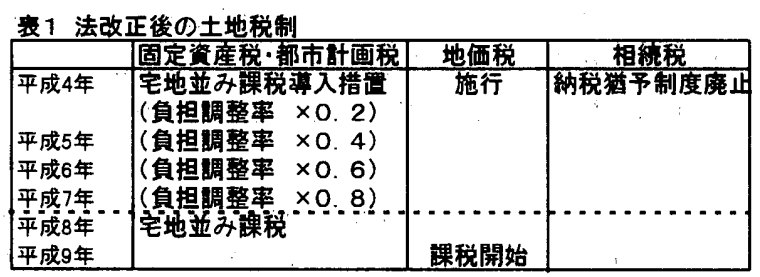

県、愛知県、大阪府等が多くなっている。茨城県、三重県の面積が 少ないのは、特定市が少ない（茨城県； 4 市、三重県；2市）ため で汤る。
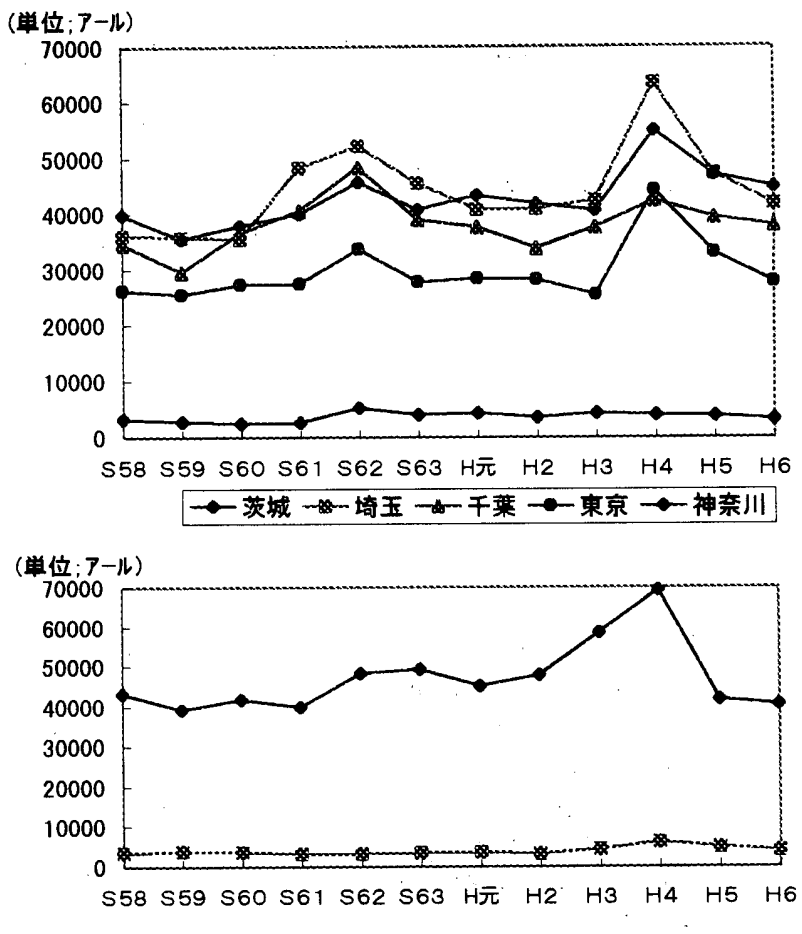

愛知 $-88-$ 三重

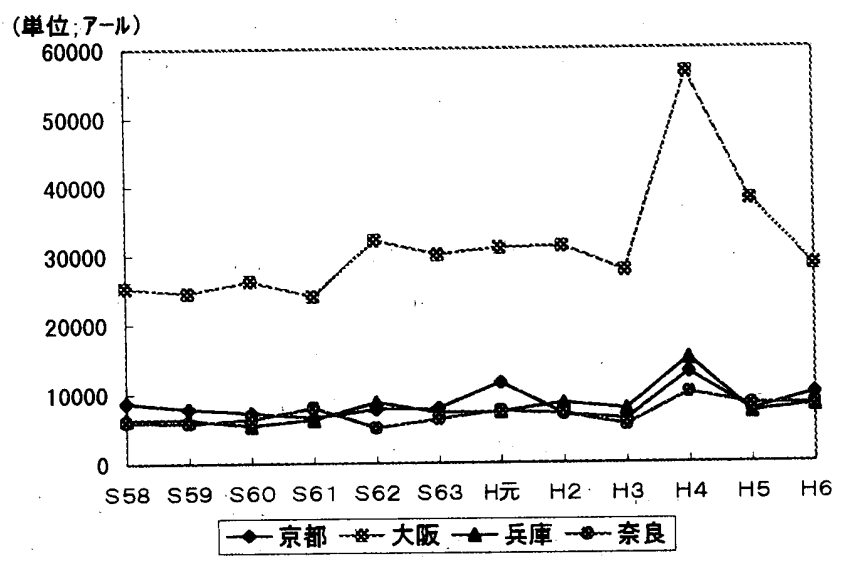

图1 特定市街化区域内鹿地転用面稆の推移

\begin{tabular}{|c|c|c|c|c|c|c|c|}
\hline & 生产程地面䆄 & 宅地化曹地面䅡 & 坛用面䅡 & 耺用害合 & 住宅目的面䅡 & 住害吾合 & 住宅事 \\
\hline 茨城県 & 59 & 623 & 139 & $22.3 \%$ & 104 & $16.7 \%$ & $74.8 \%$ \\
\hline 埼玉県 & 1,896 & 5,745 & 2,249 & $39.1 \%$ & 1,124 & $19.6 \%$ & $50.0 \%$ \\
\hline 千葉量 & 1.091 & $4,513 i$ & 1492 & $33.1 \%$ & 926 & $20.5 \%$ & $621 \%$ \\
\hline 東京都 & 3,983 & 3,012 & 1,264 & $42.0 \%$ & 815 & $27.1 \%$ & $64.5 \%$ \\
\hline 神奈川県 & 1,382 & 4,635 & 1,824 & $39.4 \%$ & 1,143 & $24.7 \%$ & $62.7 \%$ \\
\hline 首都圈計 & 8,411 & 18,528 & 6,968 & $37.6 \%$ & 4,112 & $22.2 \%$ & $59.0 \%$ \\
\hline 愛知県 & 1,591 & 7,000 & 1,886 & $26.9 \%$ & 803 & $11.5 \%$ & $42.6 \%$ \\
\hline 三重県 & 270 & 809 & 179 & $22.1 \%$ & 104 & $12.9 \%$ & $58.1 \%$ \\
\hline 中部粗計 & 1,861 & 7,809 & 2,065 & $26.4 \%$ & 907 & $11.6 \%$ & $43.9 \%$ \\
\hline 京都府 & 1,063 & 874 & 359 & $41.1 \%$ & 97 & $11.1 \%$ & $27.0 \%$ \\
\hline 大阪府 & 2,479 & 3,523 & 1,612 & $45.8 \%$ & 600 & $17.0 \%$ & $37.2 \%$ \\
\hline 兵庫県 & 616 & 1,069 & 389 & $36.4 \%$ & 190 & $17.8 \%$ & $48.8 \%$ \\
\hline 奈良県 & 640 & 1,555 & 333 & $21.4 \%$ & 112 & $7.2 \%$ & $33.6 \%$ \\
\hline 近畿䁬計 & 4,798 & 7,021 & 2,693 & $38.4 \%$ & 999 & $14.2 \%$ & $37.1 \%$ \\
\hline 全国合計 & 15,070 & 33,358 & 11,726 & $35.2 \%$ & 6,018 & $18.0 \%$ & $51.3 \%$ \\
\hline
\end{tabular}

注)生産緑地面樻·宅地化農地面䅡は平成4年の面樌

転用面積・住宅目的面積は平成4年から7年の罢計 


\section{2-2 市街化区域内農地の推移と宅地化農地の転用状況}

次に建設省「宅地供給の現状と対策」 ${ }^{6)}$ より、生産緑地法改正後 の市街化区域内農地転用面積の資料を用いて、宅地化農地の推移を 検討する。ここで、転用状況把握のために、転用割合、住宅割合、 住宅率を以下のように独自に定義し、それに基づいて算出した。

転用割合 $=$ 転用面積 $/$ 宅地化農地面積（\%)

住宅割合=住宅目的面積 /宅地化農地面積（\%）

住宅率=住宅目的面積 /転用面積（\%)

表 2 に、各都府県別の転用状況一覧を示す。生産緑地面積、宅地 化農地面積は各都府県における平成 4 年（生産緑地指定時）の面積 である。転用面積および住宅目的面積は平成 4 年から平成 7 年の届 出面積の合計である。

転用割合が最も高いのは大阪府で45.8\%であり、住宅割合では東 京都であるが、住宅率は茨城県がもつとも高く転用の $75 \%$ が住宅で ある。首都圈では、どの都県においても住宅率が5割を超えており、 住宅への転用が多い。近畿圈では奈良県を除く各府県で転用割合が 高いものの、住宅割合は平均で $14.2 \%$ で住宅率は3割程度である。 中部圈では全体に比べ転用割合が低い。

宅地並み課税が実施された平成 4 年以降の全国での特定市街化区 域内農地の推移を図 2 に示す。平成 4 年の数值は生産緑地指定時の 面積である。平成 5 年の数值は、前年 1 年間で転用された面積を引 いた值であり、平成 5 年当初の面積に等しい。それ以降も同様であ る。生産緑地面積は各年での大きな変化は見られないが注4)、宅地 化農地は平成 8 年には、平成 4 年の面積に対し約 $25 \%$ 減少している。

図 3 は宅地化農地の推移を示す。平成 4 年の宅地化農地面積は全 国合計で 33,358ha であり、これを縦軸にとる。平成 5 年の数值は、 平成 4 年に転用された農地面積と、住宅への転用面積を示す。平成 8 年までの転用面積の累計は $11,070 \mathrm{ha}$ で、33.2\%である。そのうち 住宅への転用は $18.0 \%$ 6,018haである。

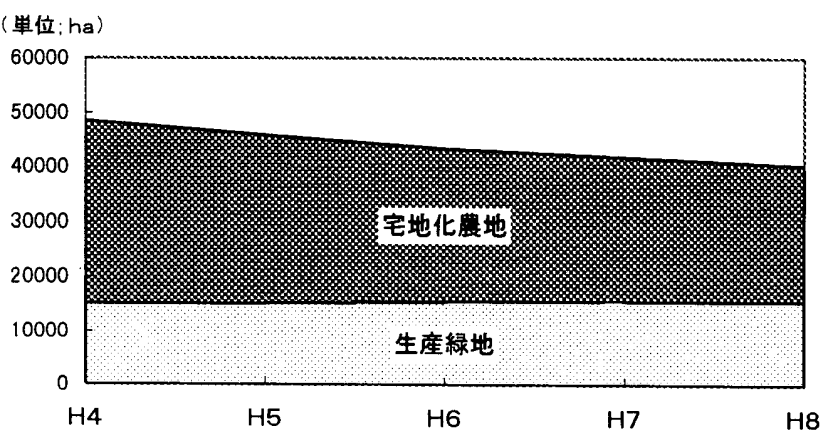

図2 特定市街化区域内莀地の椎移

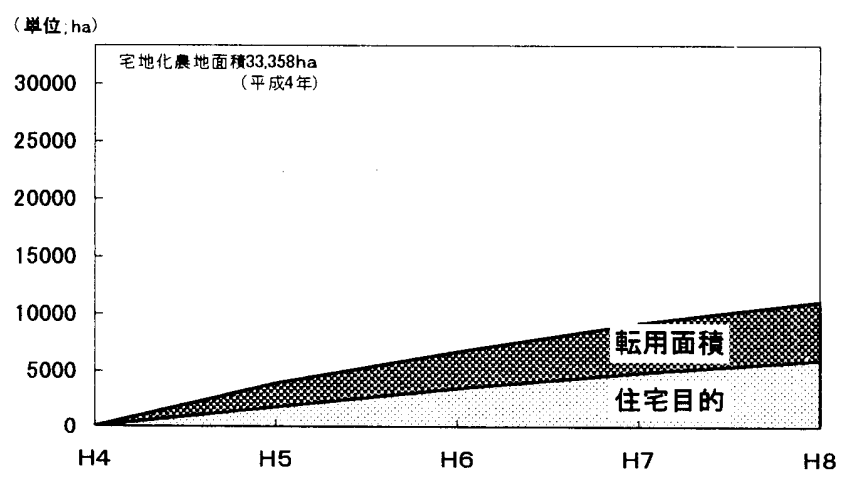

図3 宅地化蔍地の推移

\section{3. 特定市における市街化区域内農地の用途別転用状況}

これまで農林水産省、建設省の資料に基づき、農地転用の概況を 検討した。しかしこれらの資料では、宅地化農地の転用用途に関し て、転用面積および住宅転用面積までしか把握できない。そこで、 各都市圈より転用面積の多い神奈川県、愛知県、大阪府を取り上げ、 特定市市街化区域内農地の用途別転用状況についてより詳細に考察 する。調查は、各府県農政担当課集計の資料を基にその中から特定 市を選び、独自に集計し、検討した。

3-1 用途別転用面積の推移

用途別転用面樌を住宅用地、鉱工業用地、学校用地、公園・運動 場（大阪府では公園・運動場を含む公共施設用地）、道水路、その 他の 6 区分に分類し、図 4 に示す。神奈川県では各年度とも住宅率 が5割を超えている。平成3年前後に少し割合が減少しその他の用 途への割合が増加している。その他の用途への転用は各年度とも $30 \%$ 前後である。愛知県では平成 4 年まで住宅率が約 5 割であり大き な変化はみられなかったが、平成 5 年からは $60 \%$ 近くまで増加して いる。その他は各年度とも40\%前後で、住宅と同じ程度の割合を占 めている。

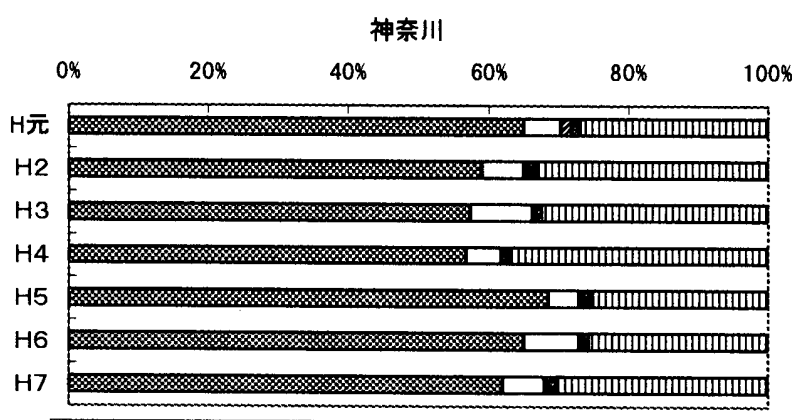

因住宅口鉱工業回学校曰公園·運動場口道水路·鉄道 凹その地
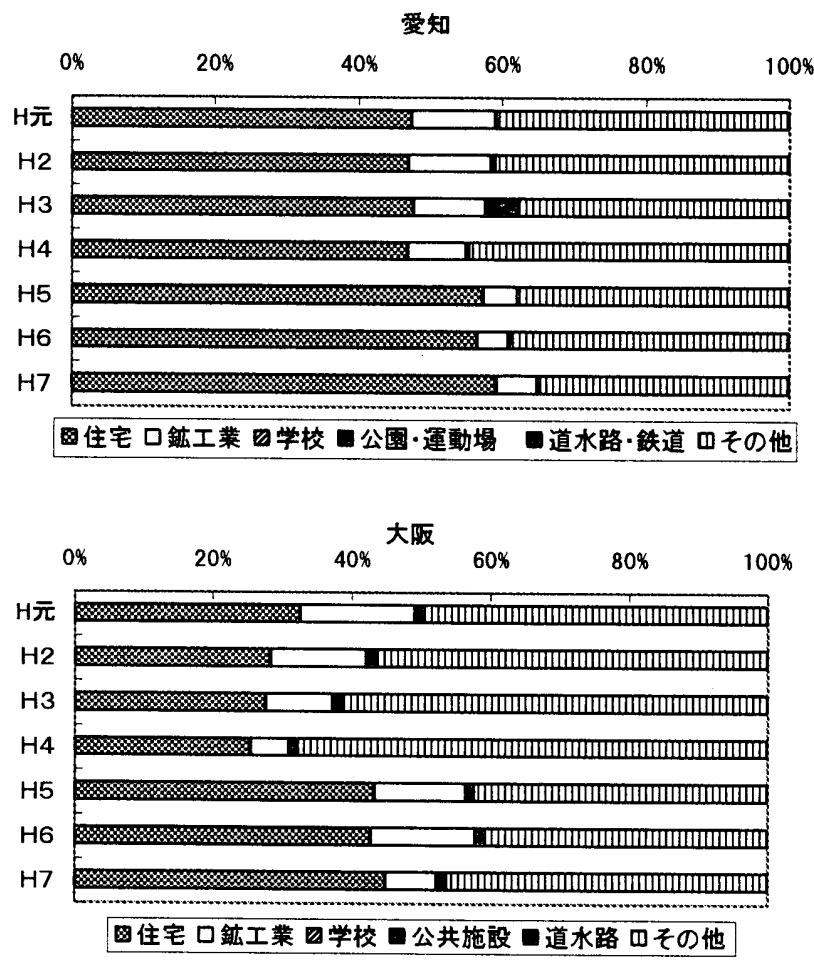

図4 用途別転用割合の推移 
大阪府では住宅率は3府県の中で最も低いが、平成 5 年からは $40 \%$ に增加しており、増加率は最も大きい。またその他は3府県で最も 高い割合を示し、50\%近くを占めている。宅地並み課税の開始直後 の平成4年には、その他が約70\%まで增加している。各府県、各年度 をみても、学校、公園・運動場への転用は非常に少ない。

次に、平成 4 年の宅地化農地面積に対する転用割合と住宅割合を 図 5 に示す。神奈川県では宅地化農地の $38.9 \%$ が平成 7 年までに転 用されており、そのうち住宅割合は $24.6 \%$ あり、全転用の6割を 占めている。愛知県では宅地化農地の $26.8 \%$ が転用されたに過きず、 住宅割合は $14.4 \%$ で住宅率は約5割であることから、比較的住宅目 的の転用が多いことがわかる。それに対し大阪府では神奈川県と同

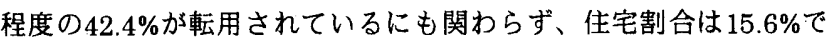
全転用の約 3 割に過きない。注(5)

以上のように、各府県で転用の状況は異なっている。大阪府は全 国でも転用割合が最も高いため、比較的転用の傾向が把握しやすい。 そこで、4 章では大阪府の一市を取り上げる。
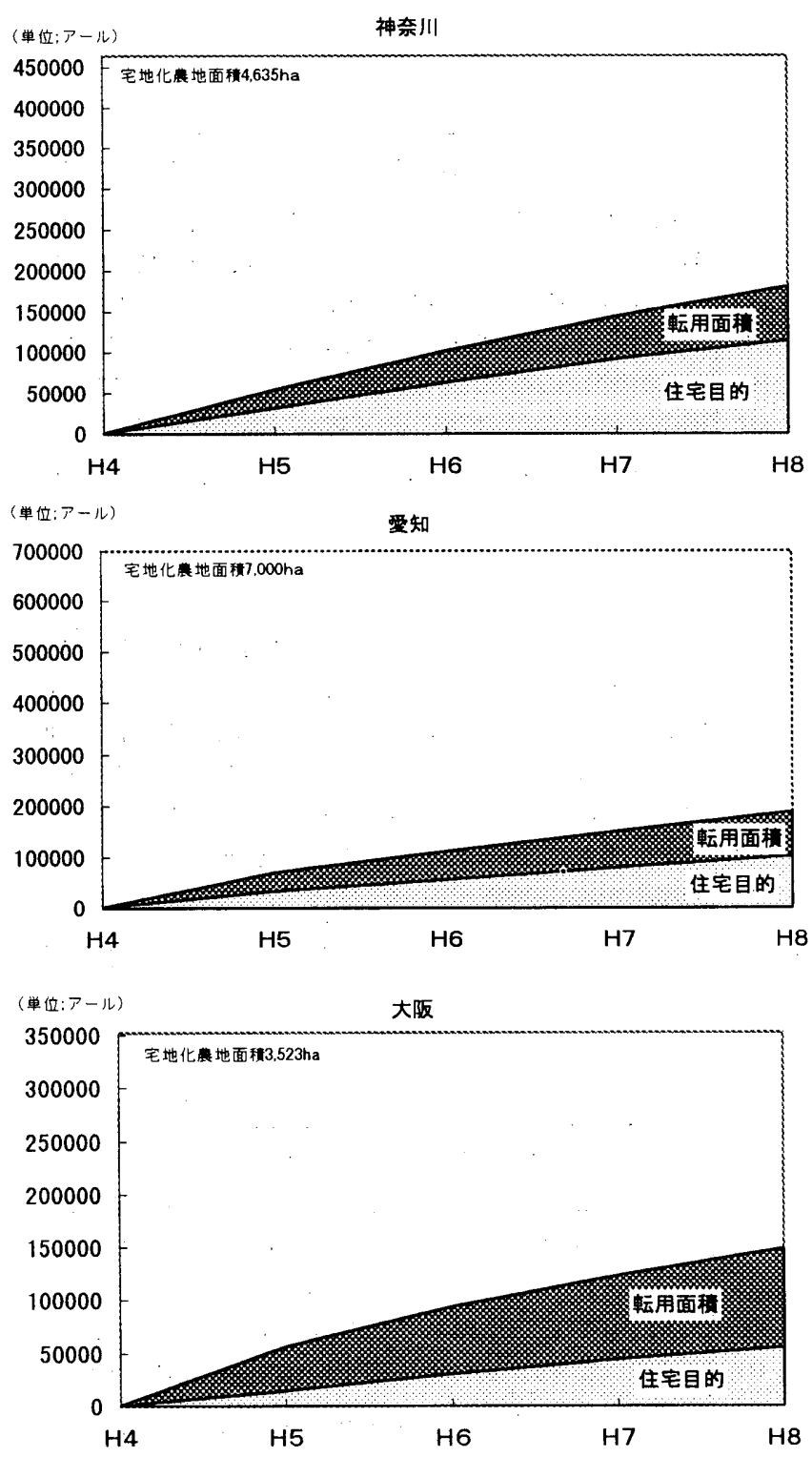

图5 宅地化農地面栍に対する転用面㮴の椎移
3-2 特定市別市街化区域内農地の転用の推移

ここでは、各府県において特定市ごとに市街化区域内農地の推移 を比較する。各特定市において生産緑地指定時の指定面積、市街化 区域内農地面積を基に、生産緑地指定率を算出し、検討に用いる。

（生産緑地指定率＝生産緑地指定面積／市街化区域内農地面積 （\%）と定義する。）

神奈川県では、生産緑地指定率は最も低い厚木市で $10.0 \%$ 、最も

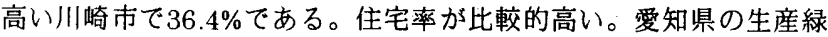

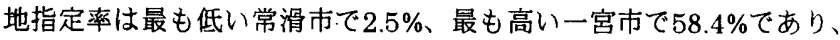
指定率の差が大きい。転用割合は他府県に比べ低く、住宅割合も低 い。住宅率は $50 \%$ 前後の市が多い。大阪府の生産緑地指定率は最も 低い門真市で $17.7 \%$ 、最も高い高㭇市で58.3\%であり、指定率が全 体的に高い。また他県に対して転用割合が高い。しかし、住宅割合 はどの市も20\%前後であり全体的に割合が低い。住宅率は30～40\% である。生産緑地指定率と転用割合の関係を図 6 に示す。一般的に

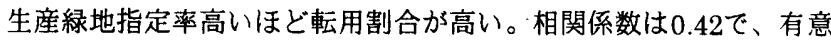
水準 $1 \%$ において弱い相関があるといえる。

\section{4. 吹田市における農地転用状況}

これまでは、全国の転用状況について検討した。しかし、3-1で みた用途別転用面積の推移で「その他」に分類されるものが多くな つているがその内容については不明である。また住宅への転用につ いて、供給住宅がどのような住宅であるのかを国、都道府県の資料 を基に把握することは難しい。そこで大阪府吹田市を事例として取 り上げ、より詳しい用途別転用、供給住宅の内容等について検討す る。吹田市を事例としたのは、大阪市に隣接し宅地化要求が高い、 大阪府内で転用割合が平均的である、市全域が市街化区域である等 の理由からである。また、図6において○印が、吹田市にあたる。 生産緑地指定率は全国平均(31\%)を10ポイント超える $42.5 \%$ ああり、 転用割合は全国平均の $35.2 \%$ を 24 ポイント超える59.9\%である。

平成元年から平成 8 年について、吹田市農業委員会「農地転用 届」を閲覧し、農地の用途別転用面積を集計した。また届出の中か ら住宅への転用を抽出し、その地番を住居表示に置き換え、吹田市 建築指導課「建築計画概要書」と照らし合わせて供給住宅を特定し た。供給住宅の内容として、共同住宅・戸建住宅の別、住戸専有面 積を調查した。

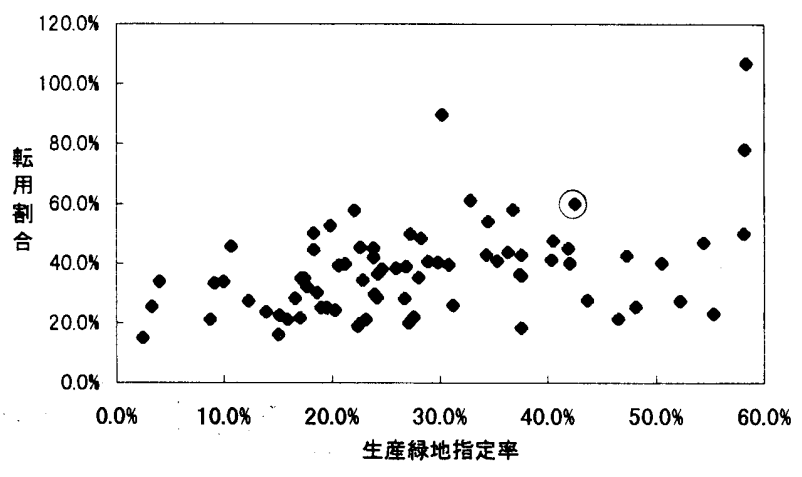

四6 生産緑地指定事と転用割合の関係 
4-1 吹田市の市街化区域内農地の概況

大阪府では平成 4 年 11 月に生産緑地地区の指定が行われた。大 阪市の北側に隣接する吹田市では、263ヶ所、合計面積63.1haが生 産緑地として指定された。生産緑地指定率は $44 \%$ あるる。残りの 85.3ha、 $56 \%$ が宅地化農地を選択した。平成7年までに51.1haが転 用され、そのうち19.6haが住宅への転用である。指定時の宅地化 農地面積に対する転用割合は $59.9 \%$ 、住宅割合は $23.0 \%$ ある。

\section{4-2 農地転用の推移}

図 7 に平成元年から平成8年までの吹田市における農地転用の推 移を表す。農地転用は宅地並み課税開始と前後する平成 3 年、平成 4 年に急激に增加している。注6) 平成 2 年には 158 件 $84,002 \mathrm{~m}^{2}$ であっ たものが、平成 3 年 258 件 $146,035 \mathrm{~m}^{2}$ 、平成 4 年 263 件 $152,527 \mathrm{~m}^{2}$ と 1.7 倍近く增加している。その後、平成 5 年からは減少し、平成7年に は転用面積の合計は平成2年を下回っている。これは全国の転用傾 向と同じである。

農地法4条5条別にみると土地所有権の移動を伴わない転用であ る4条関連の転用が大部分を占めていることがわかる。5条関連は 各年とも大きな変化はない。

次に平成元年から平成 8 年の農地転用目的の推移を図 8 に示す。 転用目的は、前述の「その他」の内容として考えられる駐車場と資 材置き場を分類し、比較的少ない学校、公共施設を「その他」に含 めた。したがって住宅、事業所、駐車場、資材置場、その他の5区

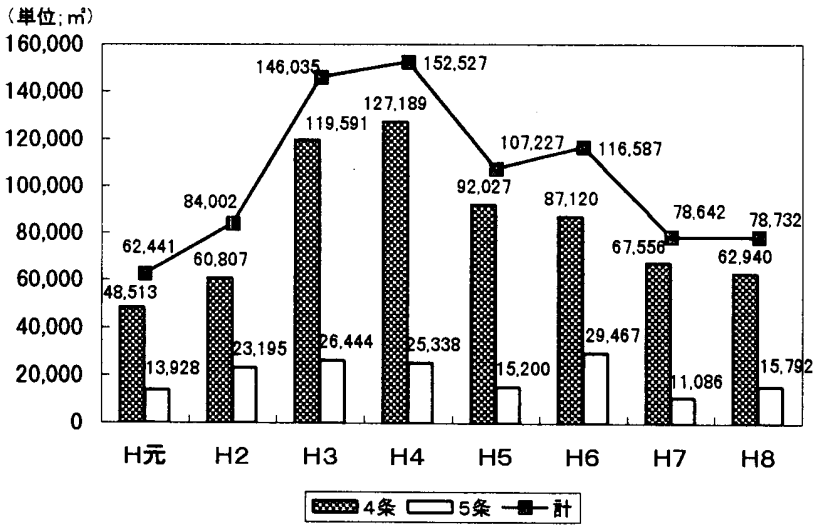

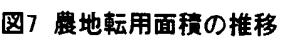

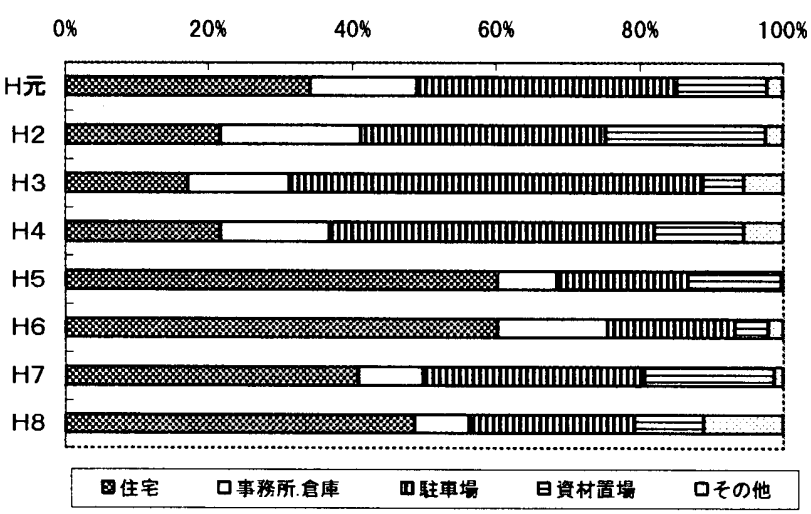

图8 用途別転用害合の推移
分に分類することとした。転用目的は住宅が $40 \%$ 、駐車場が $32 \%$ と 大部分を占める。事業所 $13 \%$ 、資材置場 $11 \%$ である。年度別推移を 見ると、宅地並み課税開始と前後する平成 3 年、 4 年は駐車場への 転用が多い。平成 3 年 $57.7 \%$ 、平成 4 年 $45.2 \%$ ある。それに対し、 住宅への転用は平成5年頃から增加し始めている。平成5年、平成6 年には約 $60 \%$ まで增加している。住宅への転用が增加した分駐車場 が減少している。宅地並み課税導入と前後して急激に転用が增加し ているが、住宅ではなく駐車場や倉庫等の暫定的な転用であること が分かる。

平成元年から平成8年までの駐車場と住宅への転用面積を比較し、 図9に示す。平成 3 年、 4 年は駐車場への転用が、その後の 5 年、 6 年には住宅への転用が多いことがわかる。平成 4 年の宅地化農地 面積に対し $79.9 \%$ が転用されている。

4-3 住宅供給戸数に対する、転用住戸の割合

次に平成元年から平成 7 年までの、各年毎の全住宅供給戸数 ${ }^{71}$ と、転用住宅戸数を比較し、それを図10に示す。住宅供給戸数は バフル経済が崩壊した平成 3 年、 4 年に戸数が減少しているが、平 成5年から再び増加し始めており、平成6年、7年では5000戸を超え る供給があった。それに対し、転用住宅は、平成4年まであまり大 きな変化は無かったが、平成5年、6年には 1000 戸を超える供給と なっている。平成 5 年には、全供給戸数の $30 \%$ をしている。しか し、平成7年には $13.2 \%$ に減少している。

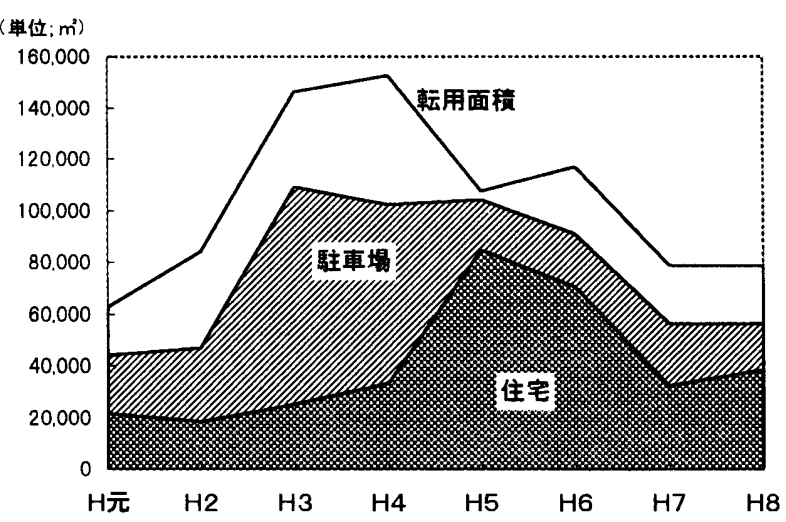

図9 駐車場と住宅への転用面程の推移

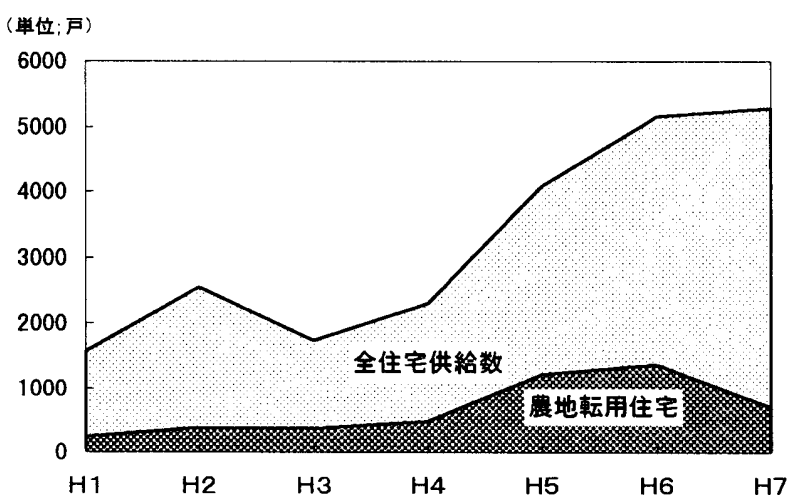

图10 住宅供給戸数に対する転用住戸の割合 


\section{4-4 住宅への転用状況}

住宅への転用状況について、平成 3 年から平成 8 年までの転用住 宅の規模分布の推移を図11に示す。住宅規模で最も多いのは $60 \mathrm{~m}^{2}$ 台で $39 \%$ 、次いで $70 \mathrm{~m}^{2}$ 台の $22 \% 、 20 \mathrm{~m}^{3}$ 台の $21 \%$ となっている。年 度別推移を見ると、平成 3 年では $20 \mathrm{~m}^{2}$ 台が $40 \%$ 近くを占めているが、 $60 \mathrm{~m}^{8}$ 台は $10 \%$ 未渵にすきない。その後、平成 5 年、平成 6 年には 60 $\mathrm{m}^{2} 、 70 \mathrm{~m}^{3}$ 台の比較的広い規模の住戸が多く供給されている。平成6 年度では $60 \mathrm{~m}^{2}$ 台が半数以上を占めている。平成 7 年は再び $20 \mathrm{~m}^{2}$ 台が 增加しているが、平成8年には $60 \mathrm{~m}^{2} 、 70 \mathrm{~m}^{2}$ 台の住戸が多くなってい る。 $100 \mathrm{~m}^{2}$ 以上の住戸は戸建住宅と思われるが、毎年 $5 \%$ 程度の供 給である。

住宅形態を比較すると、共同住宅 $94.4 \%$ 、戸建住宅 $2.4 \%$ 、寮 3.3 \%となっており、圧倒的に共同住宅が多い。

\section{5．転用住宅居住者の意識}

ここでは農地転用によって供給された住宅の居住者の意識につい て検討する。平成 3 年から平成 6 年までに農地転用の届出がされた 住宅を抽出し、各住戸に調查票を配布し返送してもらう方法で、ア ンケート調查を行った。調查実施時期は平成 8 年 12 月上旬、調査 票配布数 1941 票、有効回収票 444 票、回収率 $22.9 \%$ あった。

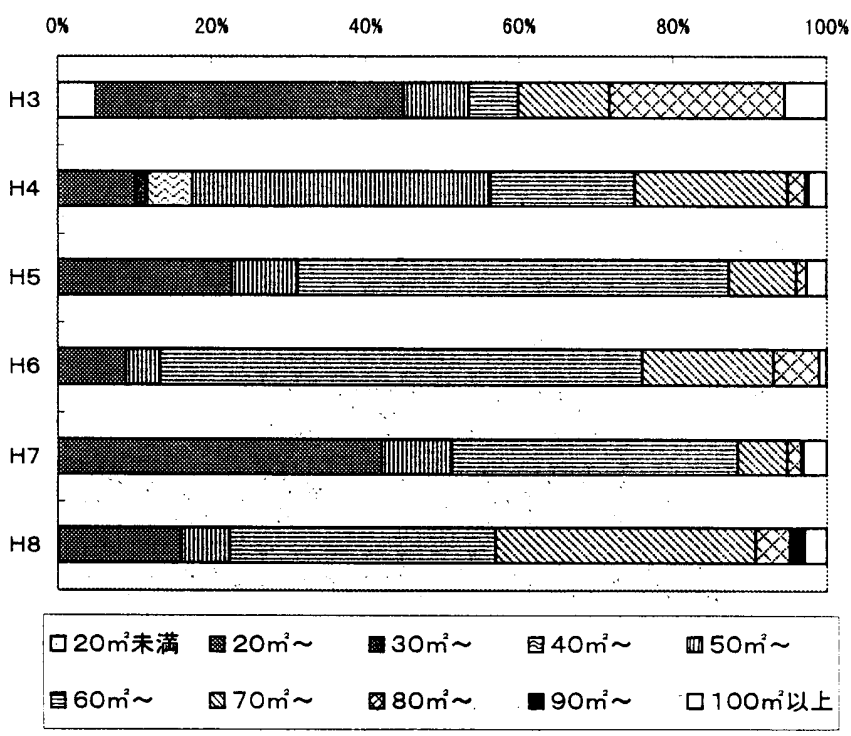

図 11 住宅規模の年度別推移

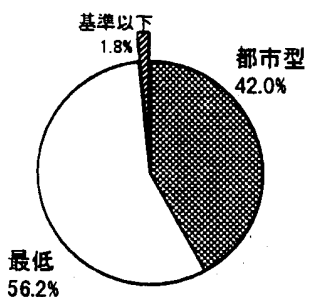

共同住宅

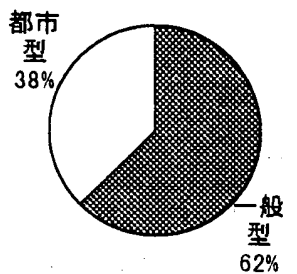

戸建住宅
5-1 転用住宅の水準

転用住宅の専有面積と居住者人数をもとに、各住戸が居住水渚を 満たしているかを比較する。共同住宅については都市型誘導居住水 準と、戸建住宅は一般型誘導居住水準と比較し、図 12 に示す。共 同住宅では、最低居住水準を満たしているが都市型誘導居住水準を

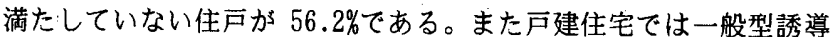

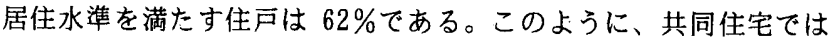
最低基準を超えているものの、誘導居住水準を超える住宅は少ない。

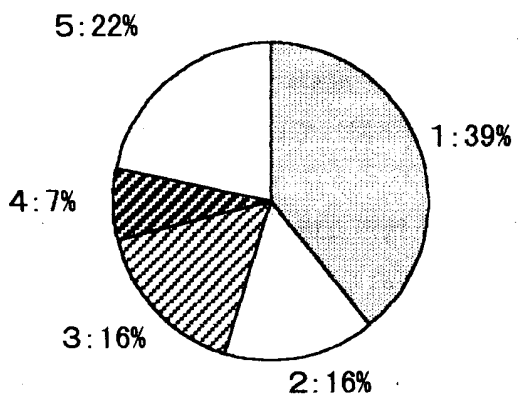

四 1:引つ越すこと
を考えている

口2:できれば 引つ越したい

ロ3:できれば住 み続けたい

4: 住み続けた い

ロ5:わからない

\section{图13 定住意向}

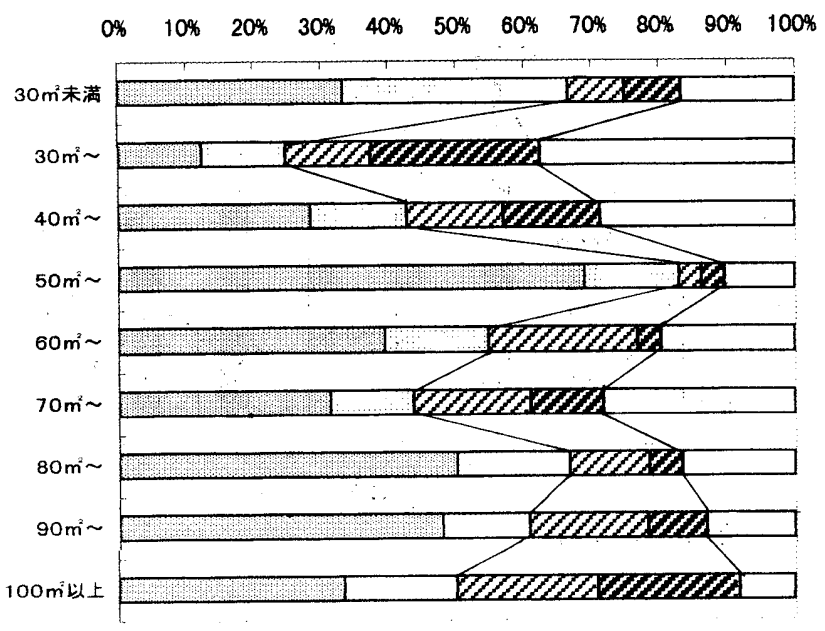

图14 住戸尃有面積別 定住意向(凡例は图13と同じ)

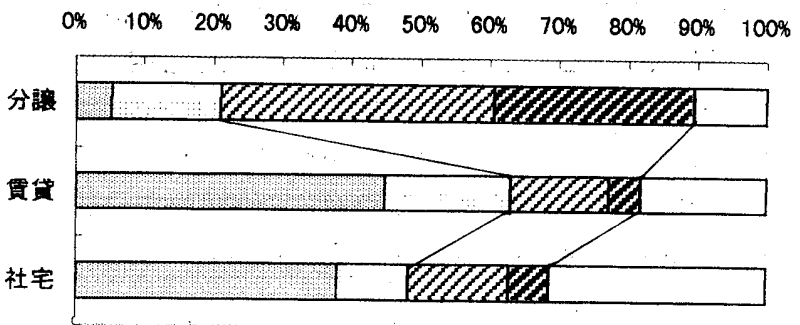

図15 住宅所有形態別 定住意向（凡例は図13と同じ） 


\section{5-2 居住者意識}

次に、居住者の意識として定住意向を比較する(図 13)。現在の 住宅に住みつづけたいかについて、(1)引越すこと考えている、(2) きれば引越したい、(3)できれば住み続けたい、(4)住み続けたい、(5) わからないの5 段階で質問した。(1)(2)と回答した人を転居希望、(3) (4)と回答した人を定住希望とすると、転居を希望する人が全体の $55 \%$ と高く、定住を希望する人は $23 \%$ に過きない。この定住意向を 住宅規模別に比較し、図 14 に示す。 $30 \mathrm{~m}^{2}$ 末满、50 $\mathrm{m}^{2}$ 台、 $80 \mathrm{~m}^{2}$ 台 で転居希望が多くなっている。特に $50 \mathrm{~m}^{2}$ 台ては $80 \%$ が転居を希望 しており、定住希望は $10 \%$ に渵たない。戸数の多い $60 \mathrm{~m}^{2}$ 台、70 $\mathrm{m}^{2}$ 台でも転居希望が約 $50 \%$ で定住希望は $30 \%$ 前後である。定住希望が 多いのは $100 \mathrm{~m}^{2}$ 以上の規模の大きい住戸である。次に、住宅所有形 態別に定住意向を比較する(図 15)。分譲住宅では、定住希望が圧 倒的に多いが、貨貸住宅では $60 \%$ 、社宅では $50 \%$ が転居希望とし ている。転用住宅の属性は分埕 $9 \%$ 、賃貸 $60 \%$ 、社宅 $31 \%$ となっ ているため、全体て定住意向が低くなっているのは貨貸住宅が多数 を占めているからであると思われる。

\section{6. 結論}

6-1 宅地化農地の転用状況

全国の転用状況を比較すると、法改正および宅地並み課税の影響 は平成 4 年に表れており、宅地化農地選択と同時に転用された農地 が多いことを示している。しかし、平成 5 年以降には転用面積は減 少しており、急激な変化は一段落したといえる。宅地並み課税の開 始から 5 年が過きた平成 7 年までに、特定市の転用面積の累計は 11,726ha で宅地化農地の約 35\%、うち住宅へは 6,018ha が転用さ れ、住宅率は $51.3 \%$ となっている。さらに吹田市の調查から、駐 車場に $30 \%$ 、資材置き場に $10 \%$ が転用されたと推測できる。これ らは暫定的な転用であるといえ、今後異なる用途へ変換されること が考えられる。したがって、未転用と暫定的転用をあわせると、平 成 4 年当初の宅地化農地のおおお施 $80 \%$ にあたる面積ついては今 後も転用の可能性があると考えられる。

6-2 供給された住宅の規模

住宅への転用については、住宅率は全国平均で 50\%を超えている が、都府県により違いがある。大部分は土地所有者による 4 条関連 の転用であるため、賃貸住宅が中心となっている。また吹田市の調 査でもわかるように、住宅供給のほとんどは共同住宅である。近年 住宅率が高まっているが、全体の転用面積が減少しているためであ り住宅が量的に增加しているわけではない。吹田市での調查でも、 住宅供給数に占める転用住宅の比率は低下している。転用住宅の規 模は、20 $\mathrm{m}^{2}$ 台、60 70 $\mathrm{m}^{2}$ 台が多く、貨貸共同住宅が中心である。 また、誘道居住水準を满たしているような、沟とりのある規模の住 宅は少なく、居住者の定住意向は全体的に低い。

\section{6-3 制度的問題点と今後の課題}

法改正により、幊貸住宅の供給という点では一定の評価ができる が、以上のように指摘した問題もある。建設省では改正後の 10 年 間で、特定市宅地化農地の 7 割にあたる約 $25,000 \mathrm{ha}$ の転用を見込 んでおり、そのうち約半分の $13,000 \mathrm{ha}$ を住宅目的の転用としてい る注 2)。しかし転用が法改正前の水㴖に低下していること、供給さ れた住宅が必ずしも良好とは言い難いこと、そして当初から混在状
況が指摘されていたこと注2)を考慮すると現行の制度だけでは法改 正の主旨が充分生かされないと言えよう。

現行制度の問題点としては、農地の転用が所有者の意思のみに任 せられていること、そのため転用時期、転用後の用途は所有者次第 であること、また住宅への転用を增加させる施策か、税の優遇措置 が中心であり、計画的な宅地化がなされていないこと、どのような 住宅が供給されるかについても所有者の考え次第であることが挙げ られる。

今回の調查から、宅地化農地の $80 \%$ については今後も転用の可 能性があり、法改正直後と異なり徐々に転用が進むと思われること が明らかとなった。今後の課題として、未転用・暫定的転用の農地 について、転用の大きな要因である土地所有者の意向を把握するこ とが挙げられる。また、その地域で今後必要とされる住宅の内容と 質を把握し、供給サイド、需要サイドの両者を連携させた供給計画 の立案か大きな課題である。そのためには転用時期を調整、誘導す るための税制度、供給される住宅の質を向上させるための融資制度 などが必要になり、供給計画に基づいた予算措置が必要となる。今 後の対応次第で状況は大きく変化し得る。所有者の意思尊重はもち ろんであるが、都市計画という視点で計画的な整備を行うことがで きる制度の構築が必要である。

農地転用の課題は今後にあり、農地と宅地の混在状況を解決し、 良好な住宅供給を行うためには、むしろ急激な変化が終わったこれ からの解決策が必要であり、一首重要であると考える。

\section{参考文献}

1）姜宗圭ほか 3 名：農住混在地域の市街地整備に関する基整的研 究, 日本建築学会大会学術梗概集 F,pp451 454,1993

2) 斎藤健一, 山本明 : 生産緑地の位置特性と利用意向一千葉市にお ける事例研究一, 日本建築学会大会学術梗概集 F-1, pp $369 \sim 370$, 1996

3）能見和哉ほか 4 名：市街化区域内農地の宅地化実態と計画的基 盤整備の課題一千葉県流山市を事例として一，日本建築学会大会学 術梗概集 F-1，pp617 618，1996

4) 三㴊卓ほか 3 名：生産緑地法改正に伴う市街化区域内農地の宅 地化動向に関する研究一横浜市北区・泉区を事例として一, 都市住 宅学, 11 号, pp237 240, 1995

5) 農林水産省構造改善局農政部農政課：農地の移動と転用，昭和 58 年 平成 6 年版

6) 建設省建設経済局宅地課：宅地供給の現状と対策，1997

7) 吹田市企画推选部調整室 : 吹田市統計書, 平成 7 年版 注

注1) 日本建築学会都市計画委員会研究愳談会：アーバンフリンジ の土地利用一生産緑地制度の改变と効果, 1997

注2) 日本建築学会関東支部住宅問題専門研究委員会 : 都市農地と 住宅まちづくり一生産緑地法改正 5 年を経て，1997 
注3）本論で使用した資料（国および都道府県の行政資料）の生産 緑地法という点から見た有用性は以下のとおりである。

「農地の移動と転用」(農林水産省) …本論 2 章で使用

この資料は一般に公刊されている。ただし生産緑地法との関係 は一切考慮されていない。しかし市ことの市街化区域内農地の転 用面積が把握できるため独自に集計を行えば年間の宅地化農地転 用面積を捉えることができる。ところが用途別転用面積は都道府 県別にしか記載されていない。そのため特定市以外の面積も含ま れてしまいこの資料からは把握できない。

「都道府県農地転用資料」(都道府県農政担当課) …本論 3 章で使用

「農地の移動と転用」の元データであり、都道府県単位で集計 されている。ただしこの資料は公刊されていない。この資料では 市町村別の用途別転用面積まで記載されているため、特定市こと の独自の集計を行うことで、宅地化農地の用途別転用面積を捉え ることができる。ただし、用途別転用の区分が住宅·鉱工業・学 校·公園運場·道水路·その他の 6 種類であり県によっては「その 他」が $50 \%$ 以上になってしまう。これは農林水産省が「農地の
移動と転用」で用いた区分に準じているためである。そのため 「その他」の内容を把握するためには各市の農業委員会が保管す

る「農地転用届」等の原本にさかのほって一から集計し直さなけ ればならない(本論 4 章参照)

注4）生産緑地面積については、追加指定・廃止により平成 8 年に は指定時に対し 415ha 増加しているが、これは指定時面積の $2.8 \%$ である。

注 5)本章で使用した数值は、各特定市での農地法 4 条 5 条に関わ る転用届出面積から算出したものである。それに対し、表 2 の数值 には法 4 条 5 条該当以外の市街化区域内の転用面積も含まれている。 その差は神奈川県 $1.3 \%$ 、愛知県 $0.4 \%$ 、大阪府 $7.7 \%$ となっている。 注6）吹田市では、平成 3 年から急激に転用が増加しているが、都 道府県レベルで比較すると、平成 3 年から増加しているのは愛知県 のみである。(図1参照) その点で吹田市はやや特殊と言えるが、 平成 3 年 10 月から生産緑地法の説明会等が開催されており、その 影響が見られるのではないかと考えられる。

（1998年5月10日原稿受理，1998年11月19日採用決定） 